\title{
Kryzysy jako impulsy zmian systemów społeczno-gospodarczych ${ }^{1}$
}

\section{Elżbieta Mączyńska}

\section{STRESZCZENIE}

Przedstawione w tym eseju analizy ukierunkowane są na identyfikowanie potencjalnych, kierunków racjonalizacji systemów społeczno-gospodarczych, służących nie tylko przeciwdziałaniu kryzysowym destrukcjom, lecz przede wszystkim charakterystycznej obecnie globalnej kryzysogenności. O konieczności poszukiwań racjonalizujących rozwiązań przekonuje nie tylko kryzys, jaki ogarnia świat w związku z pandemią COVID-19 i który obnaża systemowe dysfunkcje gospodarki globalnej. Przekonuje o tym także charakterystyczna dla współczesnego świata i występująca już przed pandemia, multiplikacja kryzysowa, czyli nakładanie się na siebie różnych kryzysów, co tworzy specyficzna, zagęszczającą się kryzysową sieć. Intensyfikują się w związku z tym dyskusje i pytania, dotyczące możliwych przyszłych kierunków zmian w systemach społeczno-gospodarczych. Pytania te są tym bardziej istotne, że wciąż utrzymuja się neoliberalne tzw. zombi-idee, czyli idee, które, mimo że rzeczywistość absolutnie nie potwierdza ich zasadności, sztucznie i w interesie waskich grup społecznych podtrzymywane są przy życiu, stanowiąc bariere przywracania ładu w wymiarze lokalnym i globalnym. W tym kontekście, w niniejszym eseju, analizowane sa odmienne od neoliberalnych koncepcje, $w$ tym koncepcja ekonomii obwarzanka autorstwa brytyjskiej ekonomistki Kate Rawarth. Ekonomistka ta wykazuje, że im bardziej wzrost gospodarczy nie jest zharmonizowany z postępem społecznym i ekologicznym, tym większa dziura w rzeczonym obwarzanku. Dziura ta zaś jest metaforą destrukcji i zaniedbań społecznych. Natomiast pole samego obwarzanka stanowi metaforę bezpiecznego i sprawiedliwego modelu społeczno-gospodarczego, eliminującego ubóstwo z jednej strony oraz niszczącą nasza planetę, konsumpcjonistyczną przesadę i nadmiar, z drugiej. Wewnętrzna, dolna krawędź obwarzanka obrazuje cele sprawiedliwości społecznej i dobrobytu, które powinny być rozszerzane, zmniejszając rzeczoną dziurę. Zewnętrzna zaś krawędź wyznacza nieprzekraczalne granice obciążeń środowiska naturalnego. Analizowane są związki tej koncepcji z ordoliberalnym modelem społecznej gospodarki rynkowej. To model ustroju z definicji ukierunkowany na ład społeczno-gospodarczy, model majacy w krajach Unii Europejskiej traktatowo-konstytucyjną rangę. Ordo bowiem znaczy ład. Jednak formalne umocowanie tego modelu nie przekłada się w pełni na społeczno-gospodarczą rzeczywistość. Dlatego też model ten wymaga wzmocnienia i dostosowania do wymogów czwartej rewolucji przemysłowej, ogarniającej obecnie świat. Przedstawione w tym eseju analizy wskazuja, że wzmocnieniu temu mogłoby służyć synergicznie połączenie intelektualnego potencjału modelu SGR i ekonomii obwarzanka. Obydwie te koncepcje łączy bowiem ich prospołeczne ukierunkowanie, harmonizujące cele gospodarcze, społeczne i ekologiczne, bilansujące system społeczno-gospodarczy, co przeciwdziała występowaniu asymetrii szkodliwych dla społeczno-gospodarczego rozwoju.

Słowa kluczowe: społeczna gospodarka rynkowa, neoliberalizm, ordoliberalizm, ekonomia obwarzanka, pandemia COVID-19, ordo; Kody klasyfikacji JEL: A14, E02, E65, O43, P20

\footnotetext{
${ }^{1}$ Esej ten jest nawiązaniem do moich wcześniejszych publikacji w "Biuletynach PTE” http://www. pte.pl/223_biuletyny_pte.html oraz w Wydawnictwie PTE w cyklu prac zbiorowych na temat społecznej gospodarki rynkowej, m.in. monografii pt. Społeczna Gospodarka Rynkowa i integracja europejska w czasach
} 


\section{Wprowadzenie}

Dwie pierwsze i obecna trzecia dekada XXI w. z pewnością zaznaczą się w historii świata, w tym także w historii gospodarczej, jako okres kryzysowej multiplikacji. Choć obecnie świat pogrąża i absorbuje głównie kryzys związany z wciąż trwająca pandemią COVID-19, której początki przypadają na przełom 2019 i 2020 r., to zarazem na ten kryzys nakładają się wcześniejsze i wciąż trwające inne rodzaje synergicznie spętlonych kryzysów, zapoczątkowanych na wiele lat przed pandemią i generujących rozmaite społeczno-gospodarcze dysfunkcje.

W literaturze przedmiotu nie brakuje dowodów na to, że kryzysowe dysfunkcje to następstwo wadliwości rozwiązań w systemach społeczno-gospodarczych głównych gospodarek świata, przede wszystkim gospodarek Zachodu, owładniętych doktryną neoliberalna promieniującą na inne obszary globu. Kryzysy zaś owe wadliwości uwydatniaja, wręcz negliżują. Dlatego też wielu badaczy zwraca uwagę nie tylko na destrukcyjny, ale także na oczyszczający, racjonalizujący wymiar kryzysów, ujawniających owe wadliwości. Między innymi Antoni Kukliński w nawiązaniu do kryzysu finansowego z 2008 r. stwierdził, że: „Ten wielki kryzys tworzy nieoczekiwane środowisko dla największej transformacji sceny globalnej w ostatnich 500 latach" [Kukliński 2010, s. 40]. Dotyczy to w pełni także obecnego pandemicznego kryzysu, w dodatku dokonującego się w warunkach ogarniającej obecnie świat czwartej rewolucji przemysłowej z jej niebywałym i wciąż rosnącym, a przy tym do końca nierozpoznanym potencjałem sztucznej inteligencji, stanowiącej połączenie potencjału materialno-fizycznego, cyfrowego i biologicznego ${ }^{2}$.

Nieprzypadkowo też obecnie w kregach naukowych, eksperckich i medialnych, zwłaszcza w krajach Zachodu, intensyfikuje się dyskurs na temat przyszłych, (po)pandemicznych kierunków zmian w systemach społeczno-gospodarczych, zmian umożliwiających przywracanie ładu w wymiarze krajowym i globalnym. Tym samym pandemia staje się swego rodzaju cezurą ustrojowo-systemowych przemian.

Niniejszy tekst wpisuje się w ten właśnie dyskurs i ukierunkowany jest przede wszystkim na identyfikowanie możliwych kierunków takich przemian, zwłaszcza w kontekście najnowszych nurtów w naukach i publikacjach ekonomicznych, dotyczacych kształtowania takich rozwiązań w systemach społeczno-gospodarczych, które ograniczałyby ryzyko występowania rozmaitych, kryzysogennych wynaturzeń hamujących rozwój społecznogospodarczy. Analizie poddawana jest przede wszystkim koncepcja społecznej gospodarki

dziejowego przełomu, red. Elżbieta Mączyńska, Piotr Pysz, PTE, Warszawa 2020, w tym rozdział pt. Społeczna Gospodarka Rynkowa. Archaiczny pleonazm czy remedium? [Mączyńska 2020a] http://www.pte.pl/ pliki/2/1/SGR_2020.pdf. W tekście tym wykorzystywane są niektóre frazy zawarte $\mathrm{w}$ tych publikacjach. ${ }^{2}$ Czwarta rewolucja przemysłowa 4.0 (Przemysł 4.0 -Gospodarka 4.0) to pojęcie wprowadzone w 2011 r. przez niemieckich specjalistów z dziedziny wysokich technologii: H. Kagermanna, W.-D. Lukasa, W. Wahlsteara i upowszechnione przez K. Schwaba, założyciela i przewodniczącego World Economic Forum w Davos [Schwab 2018]. Symbole trzech pierwszych rewolucji to kolejno: maszyna parowa, elektryczność (żarówka) i komputer. Natomiast symbolem czwartej jest sztuczna inteligencja, jako wynik połączenia świata fizycznego, cyfrowego i biologicznego. 
rynkowej (SGR), ale przede wszystkim w kontekście nowszej koncepcji ekonomii obwarzanka, autorstwa Kate Raworth. Objęcie analizami obydwu tych koncepcji, SGR i ekonomii obwarzanka, wynika przede wszystkim z traktatowo-konstytucyjnej rangi tej pierwszej i niekonwencjonalnego, nowatorskiego podejścia charakteryzującego drugą koncepcję․

Niniejsze opracowanie składa się z trzech części, z których pierwsza dotyczy kryzysowej multiplikacji i wynikającego z niej potencjału przemian systemów społeczno-gospodarczych. Część druga dotyczy wybranych kryzysogennych aspektów doktryny neoliberalnej. Kwestie te rozpatrywane są m.in. w kontekście publikacji laureata Nagrody Banku Szwecji im. Alfreda Nobla w dziedzinie ekonomii, Paula Krugmana, pt. Arguing With Zombies: Economics, Politics, and the Fight for a Better Future (Zmagania z zombi: ekonomia, polityka $i$ walka o lepsza przyszłość) [Krugman 2020]. Przedmiotem trzeciej części niniejszego opracowania jest analiza porównawcza koncepcji ekonomii obwarzanka z koncepcją społecznej gospodarki rynkowej. Analiza ta połączona jest ze stawianym na tym tle pytaniem o możliwości umocnienia wdrożeniowego potencjału tych koncepcji poprzez ich synergiczne połączenie i harmonizację. Na zakończenie przedstawiane są podstawowe wnioski dotyczące potencjalnych kierunków i realnych możliwości wdrażania przemian społeczno-gospodarczych, w tym roli koncepcji społecznej gospodarki rynkowej (SGR).

Podstawa przedstawionych w tym opracowaniu rozważań i ocen jest literatura przedmiotu, przy czym formułowane analizy i wnioski w znacznej mierze oparte sa na hermeneutyce. Stanowiące punkt wyjścia tych analiz pytania w większości mają charakter pytań otwartych, co uzasadniają nie tylko normatywne i predyktywne aspekty analizowanej problematyki oraz podejście hermeneutyczno-heurystyczne, lecz także narastający we współczesnym świecie syndrom Czarnego Łabędzia, czyli niepewności, co do kształtowania się przyszłości [Taleb 2013; Taleb 2014]. Wiąże się to nieuchronnie z ryzykiem błędów poznawczych, przed czym przestrzega m.in. amerykański ekonomista Dani Rodrik: „Ekonomiści powinni z pokora podchodzić nie tylko do tego, co wiedza, ale też do tego, ile moga się dowiedzieć” [Rodrik 2019, s. 48].

\footnotetext{
${ }^{3} \mathrm{~W}$ traktacie ustanawiającym Konstytucję dla Europy uznano, że podstawa trwałego rozwoju Unii Europejskiej będzie społeczna gospodarka rynkowa [Traktat... 2004]. Znalazło to także potwierdzenie w Traktacie z Lizbony, zmieniającym traktat o Unii Europejskiej i traktat ustanawiający Wspólnotę Europejska, zgodnie z którym: „Unia ustanawia rynek wewnętrzny. Działa na rzecz trwałego rozwoju Europy, którego podstawa jest zrównoważony wzrost gospodarczy oraz stabilność cen, społeczna gospodarka rynkowa o wysokiej konkurencyjności zmierzająca do pełnego zatrudnienia i postępu społecznego oraz wysoki poziom ochrony i poprawy jakości środowiska naturalnego. Wspiera postęp naukowo-techniczny" [Traktat... 2008]. Formalnie przyjęcie przez Unię Europejską modelu SGR jako ustrojowego wzorca dla krajów członkowskich tej organizacji, a tym samym nadanie mu tak wysokiej rangi, wynika z cech SGR i jej potencjału jako ustroju ładu. W warunkach charakterystycznego dla współczesnego świata chaosu ma to specjalne znaczenie i uzasadnienie. W Polsce już wcześniej, bo w 1997 r. nadano SGR rangę konstytucyjną, co wynika z artykułu 20. Konstytucji Rzeczypospolitej Polskiej, zgodnie z którym: „Społeczna gospodarka rynkowa oparta na wolności działalności gospodarczej, własności prywatnej oraz solidarności, dialogu i współpracy partnerów społecznych stanowi podstawę ustroju gospodarczego Rzeczypospolitej Polskiej" [Konstytucja 1997].
} 


\section{Materialny postęp versus kryzysowa multiplikacja. Społeczno-gospodarcze asymetrie}

Współczesny świat cechuje niekwestionowany postęp gospodarczy. Potwierdzaja to jednoznacznie globalnie zagregowane statystyki, w których postęp ten mierzony jest przede wszystkim wskaźnikiem PKB. W tym sensie sprawdziły się wizje wybitnego ekonomisty Johna M. Keynesa, który już przed ponad 90 latami, w 1930 r., w eseju pt. Ekonomiczne perspektywy dla naszych wnuków zapowiadał, że „za sto lat poziom życia w krajach rozwiniętych będzie od czterech do ośmiu razy wyższy niż obecnie” [Keynes 2020, s. 8]. Jeśli odnieść tę zapowiedź do obecnego poziomu PKB, to okazuje się, że w ogólnym sensie sprawdziła się $\mathrm{i}$ to ze sporą nawiązka. Obarczona jest bowiem sporym stopniem niedoszacowania ${ }^{4}$. Obecnie w wielu krajach rozwiniętych wielkość PKB, jest w porównaniu z 1930 r. nie tylko kilka, a nawet kilkunastokrotnie większa [Jakubowicz 2021]. Nie sprawdziły się jednak Keynesowskie wizje dotyczące tego, że w krajach rozwiniętych ludzie będą wolni od trosk materialnych, że w perspektywie długoterminowej kwestie ekonomiczne nie będą już stałą troską człowieka" [Keynes 2020, s. 9]. Mimo wielkiego, niekwestionowanego postępu materialnego, świat, także rozwinięty, wciąż boryka się z ogromnymi, erodujacymi popyt, dysproporcjami dochodowymi, które w znacznej mierze mają kryzysogenny charakter, a w dodatku kryzysy multiplikują.

Obecny kryzys pandemiczny nie jest niestety jedynym kryzysem w dzisiejszej rzeczywistości globalnej. Poza światowym kryzysem finansowym z 2008 r., z którego następstwami, w tym nadmiarową finansyzacja gospodarki, świat wciąż jeszcze się zmaga, można wymienić kryzys klimatyczny, demograficzny, kryzys porządku globalnego (światowego układu), kryzys globalizacji, neoliberalizmu, elit globalnych czy kryzys imigracyjny. I to z pewnościa nie jest zamknięta lista jednocześnie występujących w świecie kryzysów. W wielu bowiem sferach, wyraźne są także inne zjawiska kryzysowe, jak np. kryzys zadłużenia, kryzys gospodarki nadmiaru, niezrównoważonych systemów rolnictwa i marnotrawienia żywności, kryzys rynków pracy, postępujący kryzys społecznego zaufania, demokracji i in. Pandemia - poprzez synergiczne nasilanie się w jej wyniku kryzysowych zjawisk - dodatkowo zmultiplikowała, wzmocniła tę kryzysowa multiplikację, kryzysową sieć. Osłabia to potencjał omotanego tą siecią świata, któremu coraz trudniej z niej się wyplątywać, tym trudniej, że taki zestaw kryzysów, tworzy swego rodzaju mega historyczny węzeł gordyjski i wywoływane przez te kryzysy kumulacyjne efekty mnożnikowe [Kukliński 2010, s. 40]. Choć w takich warunkach naturalna jest skłonność do poszukiwania rozwiązań Aleksandryjskich, to zarazem wiele wskazuje, że ów gordyjski węzeł nie daje się łatwo przeciąć i świat jest zmuszony do oswajania się z kryzysową multiplikacja, dostosowując do niej sposób myślenia i postępowania. Multiplikacja taka bowiem, to jedno z następstw specyfiki mechanizmów

\footnotetext{
${ }^{4}$ Kategoria PKB jako miara dokonań gospodarczych nie była znana przed II wojna światowa. Zarazem systematyczne upublicznianie wyliczeń dochodu narodowego USA zapoczątkowane zostało w 1947 r., dzięki pracom analityczno-badawczym podjętym po Wielkim Kryzysie okresu międzywojennego przez późniejszego noblistę S. Kuznetsa [Mączyńska 2014].
} 
wolnego rynku, z jego siłą i słabościami ${ }^{5}$. Przekonuje o tym m.in. opublikowana po kryzysie z 2008 r. książka pod symptomatycznym tytułem Ekonomia kryzysu. Jej autorzy dochodza do wniosku, że: „(...) powinniśmy całkowicie odrzucić zdyskredytowaną ideę o naturalnej stabilności, efektywności i odporności nieregulowanych rynków i przyznać kryzysom należne im miejsce w ekonomii oraz systemie finansowym. Szkoda, że wielu skądinąd inteligentnych ludzi wciąż jest przekonanych, iż ostatni krach był zdarzeniem nie do przewidzenia, którego nic nie zapowiadało. Nikt by się tego nie spodziewał - twierdzą - i nikt nie zobaczy czegoś podobnego w przyszłości, przynajmniej w ciagu naszego życia. Możemy oczywiście czekać, aż następna finansowa klęska zada ostateczny cios temu niewzruszonemu samozadowoleniu. Ale możemy też przyjąć do wiadomości nową ekonomię: ekonomię kryzysu" [Roubini, Mihm 2010, s. 302]. Choć cytat ten odnosi się do kryzysu finansowego, to teza o powtarzalności kryzysów przystaje także do innych ich rodzajów, a zwłaszcza do kryzysu pandemicznego. Potwierdzają to nie tylko okołopandemiczne analizy [Taleb 2020], lecz także wyniki innych badań naukowych oraz publikacji, w tym w sposób spektakularny książka dwóch laureatów Nagrody Banku Szwecji im. Alfreda Nobla w dziedzinie ekonomii, Georga A. Akerlofa i Roberta J. Shillera, pt. Złowić frajera, Ekonomia manipulacji i oszustwa [2017], a także dzieło Krzysztofa Opolskiego i Krzysztofa Turowskiego pt. Historia ludzkiej chciwości [Opolski, Turowski 2020].

Kryzysogenna społeczno-gospodarcza rzeczywistość dowodzi, że mimo niewątpliwego postępu materialnego i technologicznego we współczesnym świecie, wciąż dalece niesatysfakcjonujące jest tempo postępu społecznego i ekologicznego, a tym samym tempo poprawy jakości życia ludzi. Jednym z najbardziej spektakularnych tego symptomów sa, z jednej strony, narastające nierówności społeczne, rozległy zakres ubóstwa i wykluczenia społecznego oraz utrzymujące się obszary głodu, a z drugiej strony, nasilające się przejawy aroganckiej rozrzutności i marnotrawstwa w bogatym świecie gospodarki nadmiaru [Wilkinson, Pickett 2011]. Nakładają się na to zjawiska anomii, czyli chaosu w systemie wartości, co wiąże się m.in. z naturą wolnego rynku i problematycznością pomiaru działalności gospodarczej i fetyszyzowaniem miary, jaka jest produkt krajowy brutto (PKB) [Stiglitz i in. 2013, Stiglitz $\mathrm{i}$ in. 2019]. Wymienione problemy pozostają w sprzeczności z teorią ekonomii jako nauki społecznej i teoretycznej podstawy działalności gospodarczej, nauki, która z definicji powinna być zorientowana na racjonalność i poprawę jakości życia ludzi.

Szczególnie wyraziście kwestie te przedstawione zostały w szczegółowym, opublikowanym w 2018 r. Raporcie Klubu Rzymskiego, autorstwa Ernsta Ulricha von Weizsäckera i Andersa Wijkmana oraz 38 innych badaczy, pod wiele mówiącym tytułem Ejże! Kapitalizm, krótkowzroczność, populacja i zniszczenie planety. Już same tytuły można traktować jako swego rodzaju syntezę dotyczaca groźnych nieprawidłowości cechujących współczesny świat oraz swego rodzaju memento, przestroge przed dalszymi jego wynaturzeniami [Weizsäcker,

\footnotetext{
${ }^{5}$ Szerzej przedstawiłam te kwestie w opublikowanym w monografii zbiorowej eseju pt. Zniewolony konsument na wolnym rynku w gospodarce globalnej. Destrukcyjne następstwa i możliwości przeciwodziałania [Mączyńska 2020b; Mączyńska 2021].
} 
Wijkman 2018]. Wystarczy przytoczyć tu niektóre tytuły rozdziałów i podrozdziałów owego Raportu: Świat w chaosie; Różne rodzaje kryzysu i poczucie bezradności; Finansjalizacja: zjawisko chaosu; Niezrównoważone systemy rolnictwa i żywności; Przerażajaca "osobliwość" $i$ "techniki wykładnicze"; Jeszcze raz mit PKB: traktowanie kosztów, jakby były korzyściami; Kapitalizm stat się arogancki; Porażka doktryny rynkowej; Błędy filozoficzne doktryny rynkowej; Filozofia redukcjonistyczna jest ptytka i nieodpowiednia; Nadużywanie techniki; Luki pomiędzy teoria, edukacja a rzeczywistościq społeczna.

Te przedpandemiczne ostrzeżenia świadczą, że choć kryzysowe zjawiska we współczesnym świecie łączone sa obecnie przede wszystkim z pandemia, to jednak istnieje dostatecznie wiele dowodów na to, że ich podłoże jest bardziej złożone i ma charakter systemowy, strukturalny, wynikający z wynaturzeń neoliberalnego kapitalizmu. Pandemia jedynie silniej je uwydatnia, ujawniając nieodporność współczesnych gospodarek na kryzysowe zagrożenia. Dlatego też trudno uznać za zasadne tak obecnie popularne w okołopandemicznym dyskursie hasło-życzenie „powrotu do normalności”. W związku z owa poprzedzająca pandemię kryzysową multiplikacja, trudno bowiem uznać przedpandemiczne lata za okres pełnej normalności ${ }^{6}$.

Choć destrukcyjny wpływ pandemii na funkcjonowanie gospodarki globalnej jest ewidentny, to zarazem nie brakuje dowodów, że skala destrukcji byłaby jednak znacznie mniejsza, gdyby systemy społeczno-gospodarcze tak wielu krajów nie były tak mało odporne na kryzysowe zagrożenia, gdyby większa ranga przypisywana była kwestiom społecznym i ekologicznym, zwłaszcza zdrowiu publicznemu. Noblista Joseph. E. Stiglitz, identyfikując słabości coraz bardziej zglobalizowanych i wzajemnie powiązanych gospodarek, poddanych doktrynie neoliberalnej i dyktatowi zysku, stwierdza wręcz, że „stworzyliśmy system, który jest bardzo podatny na pandemię" [Stiglitz 2020a, s. 10]. Dlatego też Stiglitz upatruje w pandemicznym kryzysie impulsy wymuszające naprawę i trwałe zmiany kapitalizmu w taki system, w którym przezwyciężone zostaną niebotyczne asymetrie dochodowe, w system, który będzie służyć całemu społeczeństwu, a nie tylko wybranym, uprzywilejowanym grupom [Stiglitz 2020a; Stiglitz 2020b].

Jednak, jak wynika z historii gospodarczej, kryzysowe lekcje nie zawsze są odrabiane dostatecznie starannie, a pamięć kryzysowa przeważnie bywa krótka. Przy tym podłoże krachów bywa ignorowane, a leczenie nader często koncentruje się nie na eliminowaniu przyczyn schorzeń, lecz na łagodzeniu ich objawów. Potwierdzają to chociażby doświadczenia związane z kryzysem finansowym z 2008 r. Krótkość kryzysowej pamięci tworzy urodzajne podglebie dla kolejnych kryzysów i ich multiplikacji.

\footnotetext{
${ }_{6}$ Pandemia ta skutkuje ogromem śmiertelnych ofiar wśród ludzi oraz głębokimi kryzysowymi zjawiskami w gospodarkach, jak też $\mathrm{w}$ relacjach społeczno-gospodarczych $\mathrm{w}$ wymiarze krajowym i globalnym. Ciagłe jeszcze trwanie pandemii sprawia, że istotnie zmieniają się statystki dotyczące jej następstw, a w dodatku dane statystyczne są dalece niepełne i obarczone znacznym ryzykiem niedoszacowań i błędów. Dlatego też tu ograniczam się jedynie do informacji, że dotychczas (wg oficjalnych danych WHO z lipca 2021 r.) od początku pandemii z powodu COVID-19 zmarło 4136518 osób, w tym w Polsce ponad 75235 [WHO 2021].
} 
Nakładanie się i rosnąca częstotliwość kryzysów to zarazem zarówno czynniki sprawcze, jak i skutki tego, że coraz bardziej uwydatniającą się cechą współczesnego świata jest jego spękanie, wyrażające się w występowaniu i nasilaniu się rozmaitych dychotomicznych zjawisk, asymetrii, zwłaszcza dochodowych, i braku harmonii w kształtowaniu globalnej rzeczywistości społeczno-gospodarczej. Jednym ze spektakularnych przejawów nieprawidłowości jest rozwój i rosnąca siła oligopolistycznych, przeważnie słabo uwrażliwionych społecznie i ekologicznie przedsiębiorstw, zwłaszcza gigantów cyfrowych (tzw. GAFAM - Google, Apple, Facebook, Amazon, Microsoft). Skutkuje to - zagrażająca wolnej konkurencji - horyzontalną koncentracja władzy na wielu strategicznych poziomach, w tym obejmujących centra danych, systemy operacyjne, oprogramowanie, przeglądarki, komunikatory internetowe i inne [Galloway 2017].

Przestrogą przed kryzysogennymi zagrożeniami są także wyniki badań prowadzonych przez brytyjskiego ekonomistę Paula Colliera. Autor ten wskazuje na swego rodzaju „żarłoczność”, niesprawiedliwość, dominującego w krajach Zachodu, neoliberalnego systemu społeczno-gospodarczego i cechujący go egoistyczny indywidualizm, kreujący narastanie nierówności i „społeczeństwo rottweilerów” [Collier 2017; Collier 2018].

Także francuski ekonomista Thomas Piketty traktuje narastanie nierówności jako podstawowe schorzenie współczesności. Podkreśla rosnące znaczenie różnic nie tylko dochodowych, ale przede wszystkim różnic w bogactwie majątkowym, co wiąże się zwłaszcza z majątkiem odziedziczonym. Piketty traktuje to jako symptom powrotu do swego rodzaju XIX-wiecznego, dynastycznego, „ojcowskiego” kapitalizmu.

Obok nierówności społecznych, szczególnie dalekosiężnym i kryzysogennym wypaczaniem rzeczywistości są mankamenty pomiaru społeczno-gospodarczych dokonań, w tym niedostatki PKB jako miary osiagnięć społeczno-gospodarczych i charakterystyczne dla kilku minionych dekad fetyszyzowanie tej miary, mimo że odzwierciedla ona wyłącznie dokonania rynkowe, z pominięciem działań nierynkowych, np. wolontariatu, prac opiekuńczych $\mathrm{i}$ innych prac $\mathrm{w}$ gospodarstwach domowych. Stąd też obecnie coraz bardziej krytycznie

\footnotetext{
7 Piketty postrzega nierówności jako zjawisko społeczne napędzane przez system społecznogospodarczy, zwłaszcza przez rozwiązania instytucjonalne [Piketty 2020]. W rozmowie z Steinmetz-Jenkinsem dla czasopisma „The Nation", neoliberalną formę kapitalizmu określa jako „hiperkapitalizm”, będący „rodzajem społeczeństwa własnościowego na sterydach”. Zastrzega przy tym, że woli używać pojęcia ideologii neopropretoriańskiej ("neoproprietarian" ideology) zamiast neoliberalizmu, aby podkreślić kluczową rolę stosunków własności i uniknąć niejasności związanych z ideą liberalizmu [Steinmetz-Jenkins 2020]. To nowe pojęcie dodatkowo uwypukla problem narastania nierówności majątkowo-dynastycznych. Pozycja propretorów, czyli właścicieli zmieniała się historyczne. Piketty wskazuje na rosnące nierówności majątkowe w latach 1815-1914 w kapitalistycznych mocarstwach kolonialnych i umacnianie się klasy właścicieli, lata 1914-1945 określa jako okres osłabienia klasy właścicieli w związku z rozwojem idei socjaldemokratycznych, lata 1945-1990 charakteryzuje jako niedokończony rozwój społeczeństw socjaldemokratycznych, po tym okresie następuje nawrót to ideologii społeczeństwa właścicieli, co dodatkowo było umacniane poprzez postkomunistyczną transformację, $\mathrm{w}$ tym prywatyzację i co stymulowało wzrost "nativist-proprietarian”. Wszystko to tworzyło podłoże sprzyjające ideologii neopropretariańskiej. Jej umacnianiu sprzyjał preferujący najbogatszych "dumping podatkowy" i „dumping socjalny” [Piketty 2020, s. 124 i nast.]. Szerzej na ten temat: [Mączyńska 2020b].
} 
oceniane są takie modele polityki gospodarczej, w której absolutnym priorytetem jest wzrost gospodarczy. A taki właśnie priorytet cechuje system neoliberalny [Skidelsky 2011]. Stąd też obecnie zarysowywane sa wstępne koncepcje tzw. post-PKB-owskich modeli polityki społeczno-gospodarczej, w których więcej uwagi poświęca się czynnikom jakościowym, w tym społecznym, ekologicznym i kulturowym oraz wyznaczanym w systemie społeczno-gospodarczym priorytetom. Tym samym wskazuje się na konieczność systemowych przemian, zmian społeczno-gospodarczego modelu.

Modelem, który co najmniej od czterech dekad dominował i wciąż dominuje w kształtowaniu społeczno-gospodarczej rzeczywistości jest model kapitalizmu, podporządkowany doktrynie neoliberalnej, $\mathrm{z}$ charakterystycznym dla niej fundamentalizmem rynkowym i związanym z tym trendem do sprowadzania do minimum roli państwa w kształtowaniu polityki społeczno-gospodarczej.

\section{Neoliberalne i pandemiczne destrukcje - zwiastun systemowych przemian(?)}

Szeroko opisywane w literaturze przedmiotu, charakterystyczne dla współczesnego świata dysfunkcje objaśniane sa na różne sposoby. Jednak mimo różnic zawsze tego typu analizy prowokuja pytanie o sprawność systemu społeczno-gospodarczego. To zaś łączy się z pytaniem o rolę teorii ekonomicznej w kształtowaniu społeczno-gospodarczej rzeczywistości. I tu literatura przedmiotu dostarcza wielu dowodów na to, że ów nieład jest w znacznej mierze następstwem charakterystycznego dla ostatnich dekad marginalizowania, zarówno w teorii ekonomicznej, jak i w praktyce gospodarczej, doświadczenia historycznego. Dotyczy to przede wszystkim ekonomii neoklasycznej, w tym zwłaszcza ortodoksyjnej ekonomii głównego nurtu, z charakterystycznym dla niej dążeniem do osiagnięcia doskonałości formalnej na wzór fizyki czy matematyki, co wymaga abstrahowania od szerszego społecznogospodarczego, historycznego, psychologicznego czy aksjologicznego, w tym etycznego, kontekstu badawczego $^{8}$. W tym wyraża się, cechujący metodologiczną warstwę ekonomii

\footnotetext{
${ }^{8}$ Wciąż jednak dyskusyjnym, dalekim od pełnej klarowności problemem, pozostaje klasyfikacja poszczególnych nurtów w ekonomii neoklasycznej, czyli rozwijanej od połowy XIX w. nauki na podłożu klasycznej ekonomii Smithowskiej. Watpliwości klasyfikacyjne dotyczą też teorii ekonomii w ogóle i wyodrębnianych w niej szkół czy nurtów. Objętą tą klasyfikacją ekonomię ortodoksyjną (z gr. ortodoksia, orthós - „prosty”, dóksa - „opinia, sława”) cechuje rygorystyczne przestrzeganie przyjętych, właśnie upraszczających założeń ekonomii neoklasycznej, w tym m.in. założenia o homo oeconomicus. Z kolei ekonomia głównego nurtu (main-stream economics) to pojęcie szersze, obejmujące te szkoły we współczesnej ekonomii, które bazują na części założeń ekonomii neoklasycznej (zalicza się do tego nurtu m.in. monetaryzm, teorię racjonalnych oczekiwań i teorię realnego cyklu koniunkturalnego). W odróżnieniu od ortodoksji i ekonomii głównego nurtu ekonomia heterodoksyjna (gr. héteros - „inny”) obejmuje inne nurty w teorii ekonomii, które nie mają cech ortodoksji ani ekonomii głównego nurtu. Różnice wynikaja z odmienności metod badawczych oraz zakresu i przedmiotu badań. Do heterodoksyjnego odłamu w ekonomii należą m.in. ordoliberalizm i szkoła historyczna, instytucjonalizm i neoinstytucjonalizm, ekonomia ewolucyjna, teoria wyboru publicznego oraz ekonomia behawioralna (choć i takie przyporządkowanie nie pozostaje bez kontrowersji) - vide: [Fiedor, Gorynia, Hardt 2021; Fiedor, Gorynia, Mączyńska 2020; Rutkowska-Tomaszewska, Kwaśnicki 2020].
} 
ortodoksyjnej, redukcjonizm i uniwersalizm, czyli przyjęcie zasady powszechności obowiązywania reguł ekonomii także w innych dziedzinach życia społeczno-gospodarczego, co postrzegane jest też jako swego rodzaju imperializm ekonomii [Wilkin 2014; Ratajczak 2014; Bałtowski (red.) 2016; Kołodko 2013]. Dzieje się tak, mimo że teorie ekonomiczne sa „zawsze wytworem określonego miejsca i czasu. Nie można ich rozpatrywać w oderwaniu od świata, który próbują objaśniać. A ten świat się zmienia, podlega procesowi nieustannych przemian" [Galbraith 2011, s. 15]. Jeśli więc teorie ekonomiczne mają odzwierciedlać rzeczywistość, to też muszą się zmieniać.

Jeśli się tak nie dzieje, nieuchronnie dochodzi do rozziewu między teorią ekonomiczna a rzeczywistością społeczno-gospodarczą, co zarazem stanowić może pożywkę dla kształtowania doktryn czy idei generujących ryzyko społeczno-gospodarczego nieładu. Taką właśnie, ukształtowana na podłożu ekonomii ortodoksyjnej doktryną stał się neoliberalizm. Doktryna ta odegrała zasadniczą rolę w promowaniu trzech procesów: procesu osłabiania instytucji państwa, procesu marginalizacji dobra wspólnego i osłabienia poczucia racjonalnego działania gospodarczego w sferze publicznej, procesu osłabiania rangi kultury myślenia strategicznego, na rzecz dominacji podejścia krótkookresowego [Kukliński 2010, s. 40-41]. Stąd też neoliberalizm jest niekiedy postrzegany jako rodzaj karykatury liberalizmu klasycznego. Liberalna troska o wolność jednostki, polityczne równouprawnienie i prawa człowieka zostały bowiem wypaczone przez sprowadzenie tego wyłącznie do gospodarczej doktryny [Mirowski, Plehwe 2009, s. 447]. Stąd też Harwardzki ekonomista Dani Rodrik skonstatował w 2002 r., że między neoliberalizmem a liberalizmem klasycznym - fundamentem ekonomii neoklasycznej - jest taka relacja, jak między astrologią a astronomią [Rodrik 2002].

Trzeba jednak zastrzec, że mimo wskazywania neoliberalizmu, jako głównego winowajcy obecnych społeczno-gospodarczych wynaturzeń, w literaturze przedmiotu wciąż brak jest jednoznacznej oceny tej doktryny i jej podłoża w teorii ekonomii. Oceny na ten temat są rozbieżne, choć pandemiczny kryzys zdaje się nieco przybliżać do konsensusu, czemu sprzyjaja okołopandemiczne publikacje i dyskurs ekonomiczny [Arak 2021; Galloway 2021] $]^{9}$. Publikacji na ten temat jest coraz więcej, choć wciąż ma miejsce chaos definicyjny i nader często synonimiczne traktowanie takich pojęć jak klasyczny liberalizm i neoliberalizm, w dodatku bez odniesień do ordoliberalizmu. Te trzy wymienione odmiany liberalizmu (liberalizm klasyczny, ordoliberalizm i neoliberalizm) nie dość, że są bezzasadnie traktowane jako synonimy, to w dodatku nierzadko mylone lub/i traktowane jako monolit, charakteryzowany pod hasłem „liberalizm”, bez należytego wyjaśnienia jego istoty i zróżnicowanych odmian [Maczyńska, Pysz 2014]. Nie pozostaje to bez negatywnych konsekwencji dla szlachetnej idei, jaką jest liberalizm. „Takie ideały, jak wolność, swoboda wyboru, demokracja, pluralizm, prywatna własność, przedsiębiorczość, rynek, konkurencja - to godne zabiegów pozytywy. Neoliberalizm natomiast, w sposób tyleż cyniczny, co skuteczny,

\footnotetext{
${ }^{9}$ Pierwszą kompleksowa, naukowa, choć też niepozbawioną kontrowersji próbę rozwikłania istoty i historycznych korzeni oraz ewolucji neoliberalizmu stanowi dzieło pod redakcją Philipa Mirowskiego i Dietera Plehwe pt. The Road From Mont Pelerin: The Making of Neoliberalis [Mirowski, Plehwe 2009].
} 
eksploatuje te liberalne wartości, aby transferować dochody od większości średniaków i biedaków do mniejszości zamożnych i bogatych" [Kołodko 2013, s. 37] ${ }^{10}$.

Wynaturzenia powstające na podłożu neoliberalnej doktryny, głównie na przykładzie USA, sa przedmiotem rozważań Paula Krugmana, laureata Nagrody Banku Szwecji im. Alfreda Nobla w dziedzinie ekonomii, w książce pod symptomatycznym tytułem: Arguing with Zombies: Economics, Politics, and the Fight for a Better Future (Zmagania z zombi: ekonomia, polityka i walka o lepszq przyszłość) [Krugman 2020]. Owe tytułowe Zombies, czyli żywe trupy, to w tym przypadku nie przedsiębiorstwa sztucznie podtrzymywane przy życiu, a ekonomiczne idee. To potężne idee ekonomiczne, których nie udaje się wyeliminować z życia społeczno-gospodarczego, mimo negujących te idee dowodów naukowych. Krugman dochodzi do wniosku, że dzieje się tak dlatego, że stojące za tym interesy gospodarcze i polityczne sa zbyt silne. Idee te, choć negowane przez rzeczywistość społeczno-gospodarczą i jej szkodzące, wciąż znajdują miejsce w obszarze politycznym i gospodarczym, co nierzadko łączy się z interesownym zakłamywaniem realiów. Krugman odnosi pojęcie Zombies do szeregu programów społeczno-gospodarczych, opartych właśnie na ideach/teoriach-Zombi. Choć idee te okazują się błędne, fałszywe, wciąż trwaja „pożerając ludzkie mózgi” i powracaja, sztucznie podtrzymywane przy życiu - także poprzez bodźce finansowe - zwłaszcza przez kręgi mające w tym swoje skrywane interesy.

Krugman przeciwstawia się takim teoriom-zombi jak: homo oeconomicus, austerity (czyli rzekomo ozdrowieńcza $\mathrm{w}$ warunkach recesji polityka zmniejszania deficytu budżetowego poprzez gwałtowne redukcje wydatków państwa), czy teoria skapywania (rickle-down theory), wg której nierówności społeczne, w tym dochodowe, nie stanowia problemu, bowiem przypływ, czyli bogacenie się najbogatszych unosi wszystkie łodzie, zatem bogacą się wszyscy.

Jednak wg Krugmana żadna zombi-idea nie jest tak uporczywa i w takim stopniu błędna, jak twierdzenie, że niskie opodatkowanie bogatych ma fundamentalne, korzystne następstwa dla całej gospodarki i że obniżki podatków dla najlepiej zarabiających pozytywnie wpływają na wzrost gospodarczy. Tym samym, wg tej idei, wyższe opodatkowanie bogatych jest destrukcyjne dla całej gospodarki, natomiast zmniejszanie stóp podatkowych od dochodów przyspiesza wzrost gospodarczy. Choć rzeczywistość temu absolutnie przeczy, to ta teoria-zombi jest wciąż żywa, mimo że niewiele teorii ekonomicznych zostało przetestowanych i obalonych tak dokładnie jak właśnie ona. Według Krugmana dzieje się tak, gdyż zawsze

\footnotetext{
${ }^{10}$ Kołodko zwraca przy tym uwagę na terminologiczne różnice między Europą i USA. „W USA określenia neoliberał w zasadzie nie ma w obiegu, a jeśli jest używane, to bez negatywnej konotacji, którą nadajemy mu w Europie. W amerykańskiej literaturze neoliberalizm najczęściej określany jest jako współczesny leseferyzm albo neokonserwatyzm" [Kołodko 2013, s. 37]. Z kolei francuski ekonomista Thomas Piketty, traktujący narastanie nierówności jako podstawowe schorzenie współczesności, postrzega je jako zjawisko społeczne napędzane przez system społeczno-gospodarczy, zwłaszcza przez rozwiązania instytucjonalne [Piketty 2020]. W rozmowie z Steinmetz-Jenkinsem dla czasopisma "The Nation”, neoliberalna formę kapitalizmu określa jako „hiperkapitalizm”, będący „rodzajem społeczeństwa własnościowego na sterydach". Zastrzega przy tym, że woli używać pojęcia ideologii neopropretoriańskiej ("neoproprietarian" ideology) zamiast neoliberalizmu, aby podkreślić kluczową rolę stosunków własności i uniknąć niejasności związanych z ideą liberalizmu [Steinmetz-Jenkins 2020]. To nowe pojęcie dodatkowo uwypukla problem narastania nierówności majątkowo-dynastycznych [Piketty 2020].
} 
znajdują się duże pieniądze na wspieranie fałszywych idei, ubieranych w chwytliwe, sprytne, choć nieprawdziwe argumenty, jak np. ten, że zasiłki dla bezrobotnych utrwalają bezrobocie. Krugman zarzuca zombie-teoriom szkodliwy wpływ na kształtowanie harmonijnego rozwoju społeczno-gospodarczej przyszłości [Krugman 2020; Münchrath, 2021].

Tego typu krytyczne analizy negowanych przez rzeczywistość społeczno-gospodarcza teorii-zombi, choć stopniowo i powoli, trochę na zasadzie przysłowiowej kropli drążącej skałę, przenikaja jednak do teorii ekonomicznej i praktyki. Jednym z tego przejawów jest zaznaczający się od kilku lat, a ostatnio głównie pod wpływem pandemii, trend odwrotu od zalecanej do niedawna krajom będącym w stanie recesji, czy kryzysu - polityki austerity czyli oszczędności, zaciskania pasa, polityki zmniejszania wydatków publicznych i niezadłużania się [IWF 2020]. Pandemia wyraźnie przyspiesza przemiany w podejściu do kształtowania polityki społeczno-gospodarczej i zwiększa sceptycyzm, co do zasadności bazującej na ortodoksyjnej ekonomii, doktryny neoliberalizmu. Uwydatnia zarazem konieczność optymalizacji relacji państwo-rynek. Rynek bowiem, nie może prawidłowo funkcjonować bez państwa, a państwo bez rynku. Jest to istotne tym bardziej, że badania i literatura przedmiotu, a przede wszystkim społeczno-gospodarcza rzeczywistość - w tym przywoływane tu publikacje dowodza, że i państwo, i rynek moga odgrywać zarówno konstruktywną, jak i destrukcyjną rolę. Wskazuje to zarazem na rangę racjonalizacji systemów społeczno-gospodarczych. W Polsce szczególnie wiele miejsca poświęca tej kwestii Grzegorz W. Kołodko, który analizując „niechlubną spuściznę neoliberalizmu” przedstawia zarazem nowatorska koncepcje nowego pragmatyzmu. Koncepcja ta była już przedmiotem wielu analiz i publikacji [Kołodko 2014; Bałtowski 2016; Mączyńska (red.) 2019]. Uzasadnia to zrezygnowanie z takich analiz w tym miejscu. Dlatego też, ograniczam się jedynie do stwierdzenia, że nowy pragmatyzm bardzo przystaje do ordoliberalnej koncepcji społecznej gospodarki rynkowej [Kołodko 2014; Bałtowski 2016; Mączyńska (red.) 2019]. W tej i innych wskazywanych tu publikacjach wyraźnie przebija się teza o konieczności wypracowania nowego modelu ładu społecznogospodarczego, i nowego przemyślenia relacji państwo - rynek - społeczeństwo. Najbardziej chyba zaskakującym przykładem zwrotu w tym kierunku jest, sformułowana na poczatku kwietnia 2020 r., opinia kolegium redakcyjnego „The Financial Times” (FT) - prominentnego brytyjskiego dziennika o dotychczas zdecydowanie neoliberalnym zabarwieniu [Virus... 2020] ${ }^{11}$. W tekście tym wskazuje się na konieczność zwiększenia roli państwa w kształtowaniu społeczno-gospodarczej rzeczywistości i traktowania wydatków publicznych w kategoriach inwestycji w społeczne dobro wspólne, a nie w kategoriach uciążliwych kosztów.

Tego typu zmiany stanowią zarazem jeszcze jedno potwierdzenie, że czasy kryzysów (także wojen), które z reguły obnażaja słabości, błędy w polityce społeczno-gospodarczej, wadliwość systemów społeczno-gospodarczych, prowokuja do ich zakwestionowania i do poszukiwania nowych rozwiązań ustrojowych. Kryzys zatem uczy i stwarza tym samym szansę naprawy systemu [Mazzucato 2020a; Mazzucato, 2020b].

\footnotetext{
${ }^{11}$ Tego typu oceny i ostrzeżenia są od lat formułowane w debatach i publikacjach Polskiego Towarzystwa Ekonomicznego (PTE). Informacje na ten temat, w tym publikacje i relacje z debat dostępne są na portalu PTE http: / / www.pte.pl/- vide m.in. [Mączyńska, Pysz 2020a; Mączyńska, Pysz 2020b].
} 
Historia gospodarcza wykazuje jednak, że kryzysowe lekcje mogą być odrabiane należycie, ale też mogą być pojmowane, czy wykorzystywane opacznie. I tak, Wielki Kryzys okresu międzywojennego był zaczynem wdrażania w USA przez prezydenta Franklina Delano Roosevelta programu radykalnych reform gospodarczych i prospołecznych, czyli tzw. „Nowego Ładu” (,New Deal”). Niestety, w Europie kryzys ten przyniósł nacjonalizm i faszyzm oraz umacnianie się w niektórych krajach tendencji etatystycznych. Faszyzm zaś doprowadził do II wojny światowej, która miała zgoła odmienne następstwa dla krajów zachodnich i tzw. wschodnich, przekształconych w blok socjalistyczny, z nierynkowym etatystycznym systemem społeczno-gospodarczym. Natomiast kraje Europy Zachodniej po wojnie doświadczały rozwoju wolnorynkowej gospodarki, rozpoczynając trwająca mniej więcej do końca lat 70. XX w. tzw. „złotą erę kapitalizmu”, charakteryzująca się zarówno dynamicznym wzrostem gospodarczym, jak i wzrostem dobrobytu społecznego. Spektakularne tego przejawy odnotowywały zwłaszcza Niemcy Zachodnie, gdzie po II wojnie światowej wdrożona została przez Ludwiga Erharda, ministra gospodarki w pierwszym rządzie Konrada Adenauera, ordoliberalna koncepcja społecznej gospodarki rynkowej. Skutkowało to zdynamizowaniem postępu społeczno-gospodarczego w stopniu określanym w literaturze przedmiotu jako cud gospodarczy.

Nieprzypadkowo też obecnie pandemiczny kryzys wyraźnie sprzyja wzrostowi zainteresowania ordoliberalizmem i powstałej na jego podłożu koncepcją SGR [Pysz, Grabska-Jurczuk 2021]. Przy tym generalnie w najnowszych publikacjach dotyczących kierunków zmian systemów społeczno-gospodarczych charakterystyczne jest, że przedstawiane tam rekomendacje w znacznym stopniu przystaja do koncepcji społecznej gospodarki rynkowej. Dotyczy to także koncepcji fundamentalnych zmian systemu społeczno-gospodarczego, opublikowanej wcześniej (w 2017 r.) przez brytyjską ekonomistkę Kate Raworth, w głośnej książce pt. Ekonomia obwarzanka. Siedem sposobów myślenia o ekonomii XXI wieku [Raworth 2017].

\section{Społeczna gospodarka rynkowa versus ekonomia obwarzanka}

Teoretyczna podstawę koncepcji SGR, jako modelu społeczno-gospodarczego ustroju równowagi stanowi ordoliberalizm, zapoczątkowany przed II wojną światowa teoretyczny nurt, którego prekursorem był Walter Eucken. Ordoliberalizm to koncepcja „liberalizmu uporzadkowanego" ukierunkowanego na ład społeczno-gospodarczy, na godzenie, harmonizowanie interesów gospodarczych i społecznych [Eucken 2004]. Ordo bowiem w języku starożytnych znaczy ład, umożliwiający ludziom „życie w wolności i odpowiedzialności” [Eucken 1989, s. 240]. Dla ordoliberalizmu - w odróżnieniu od neoliberalizmu - charakterystyczny jest sceptycyzm co do doskonałości wolnego rynku. Odzwierciedla to chociażby sformułowana przed ponad ośmiu dekadami teza Euckena, że „każdy rynek nieujęty w porządkujące jego spontaniczne funkcjonowanie, instytucjonalne ramy konkurencyjnego ładu gospodarczego, zawiera w sobie immanentną tendencję do samozniszczenia" [Eucken 2004, s. 31]. 
Koncepcja SGR zrodziła się na kanwie Wielkiego Kryzysu okresu międzywojennego i związanych z nim poszukiwań rozwiązań antykryzysowych. To jeszcze jeden dowód tego, że kryzysy mają - mimo destrukcyjnych następstw - także proracjonalizującą moc.

Ordoliberalna koncepcja SGR jest przedmiotem wielu publikacji, w tym także w języku polskim. Polskie Towarzystwo Ekonomiczne od lat publikuje monografie dotyczace tej problematyki oraz artykuły na ten temat, w tym w dwumiesięczniku „Ekonomista” i kwartalniku „Biuletyn PTE” (vide Literatura). Dlatego też, przedstawione tu rozważania ograniczam do podstawowych kwestii, tak by możliwa była porównawcza analiza z koncepcja ekonomii obwarzanka.

Niekwestionowaną cechą SGR jest to, że stanowi model ustroju nie tylko ładu społecznogospodarczego, lecz także ustroju dobrobytu społecznego, co wyraża tytuł dzieła współtwórcy tego modelu, Ludwiga Erharda: Dobrobyt dla wszystkich [Erhard 2012]. A obecnie nie brakuje wśród ekonomistów i innych naukowców zwolenników zastapienia słynnego Clintonowskiego hasła „Gospodarka, głupcze!” hasłem „Społeczeństwo, głupcze!” Skłaniają do tego nasilające się niepokoje społeczne, zwiększające ryzyko wystapienia rewolty społecznej, co ma podłoże w narastających nierównościach społecznych. W dodatku nie brakuje analiz, z których wynika, że obecny kryzys w największym stopniu dotyka najuboższe warstwy społeczne, zwiększając te nierówności.

Natomiast sformułowane przez Waltera Euckena tzw. zasady konstytuujące, czyli fundamentalne dla utrzymania ładu SGR oraz zasady regulujące przebieg procesów społecznogospodarczych wyraźnie ukierunkowane są na harmonizowanie interesów gospodarczych i społecznych. Eucken wskazuje na 6 takich zasad konstytuujących, w tym: konkurencyjny system cen, stabilna polityka monetarna, otwartość rynków, prywatna własność, swoboda zawierania umów i stabilność polityki gospodarczej. Ponadto wskazuje na potrzebę zasad regulujących procesy gospodarcze, ale ograniczonych do następujących sytuacji [Eucken 2004]:

- $\quad$ występowanie naturalnych i lokalnych monopoli,

- drastyczne różnice dochodowe niemożliwe społecznie do zaakceptowania,

- nieuwzględnianie w rachunku ekonomicznym przedsiębiorstw niepożądanych efektów zewnętrznych,

- $\quad$ występowanie anormalnych reakcji po stronie podaży, zwłaszcza pracy [Eucken 2004, s. 291-304].

Niezbędność takich porządkujących regulacji wynika z cech wolnego rynku, który „pozbawiony ram instytucjonalnych, kształtowanych i kontrolowanych przez politykę państwa, unicestwia konkurencję producentów, prowadząc ostatecznie do panowania oligopoli i monopoli" [Eucken 2004, s. 30-31]. Wolnorynkowa konkurencja jest w takich warunkach wypierana przez „władzę pasożytniczych podmiotów nad rynkiem i nabywcami“ [Erhard 2005, s. 16].

Już nawet tak pobieżna analiza konstytuujących i regulujących zasad SGR wskazuje, że wszystkie one dziś nie tylko nie traca na aktualności, lecz przeciwnie - zyskuja [szerzej Mączyńska, Pysz 2020a; Mączyńska, Pysz 2020b]. Problem sprowadza się jednak do braku w polityce społeczno-gospodarczej konsekwencji w realizacji zasad SGR, spychanych 
na margines na rzecz rozwiązań neoliberalnych. Mimo cech SGR jako ustroju ładu społecznogospodarczego i mimo obecnych przejawów globalnego nieładu i kryzysowej multiplikacji, nie ma jednak gwarancji, że wygra ona z neoliberalną doktryną. Dowodzą tego chociażby wskazywane już doświadczania historyczne [Mączyńska, Pysz 2020a; Mączyńska, Pysz 2020b]. Zarazem jednak doświadczenia te, w tym związane z funkcjonowaniem po Wielkim Kryzysie okresu międzywojennego programu „New Deal” oraz SGR w Niemczech, zaowocowały niekwestionowanymi sukcesami społeczno-gospodarczymi, choć jednocześnie obydwa te programy nie są wolne od kontrowersyjnych ocen. Tym niemniej badania na ten temat dowodza, że wspólną cechą tych programów, przesądzającą o efektywnościowych walorach jest ich ukierunkowanie na kwestie społeczne. Obydwa te programy łączy uwrażliwienie społeczne i zorientowanie na harmonizacje postępu gospodarczego z postępem społecznym i poprawę jakości życia ludzi.

Prospołeczne ukierunkowanie dotyczy także koncepcji fundamentalnych zmian systemu społeczno-gospodarczego przedstawionych w opublikowanej w oryginale przed pandemia (w 2017 r.) książce Kate Raworth pt. Ekonomia obwarzanka. Siedem sposobów myślenia o ekonomii XXI wieku [polski przekład: Raworth 2021]. Autorka ta wskazuje na długa listę obecnie występujących dysfunkcji społeczno-gospodarczych, podkreślając zarazem, że podstawowe z nich wynikają z niezamierzonego lub celowego mylenia pojęć, w tym utożsamiania celów społeczno-gospodarczych ze środkami ich osiagania. Sprawia to, że środek staje się celem, a właściwy cel znika z pola zainteresowania. To swego rodzaju „syndrom kukułczego gniazda”. Zdaniem Raworth, taką kukułka w gospodarczym gnieździe jest właśnie produkt krajowy brutto (PKB). Wzrost PKB przekształcił się bowiem w podstawowy cel w polityce społeczno-gospodarczej, wypierając, wydawałoby się oczywisty, fundamentalny w krajach demokratycznych cel, czyli poprawę jakości życia ludzi i dobrobyt społeczny. Błędem jest zatem utożsamianie wzrostu PKB z trwałym, zrównoważonym, harmonijnym rozwojem społeczno-gospodarczym, którego filarami są - obok wzrostu gospodarczego - postęp społeczny i ekologiczny. Sam wzrost gospodarczy bez należytego postępu społecznego i ekologicznego jest dzikim wzrostem gospodarczym, hamującym dobrobyt społeczny [Stiglitz i in. 2019; Stiglitz i in. 2013]. $\mathrm{W}$ analizach z tego zakresu ważny jest porządek terminologiczny. Ignacy Sachs zaproponował w połowie lat 90. ubiegłego wieku, żeby pojęcie „rozwój” stosować wyłącznie do takich sytuacji, gdzie ma miejsce postęp w trzech wymiarach, tj. w wymiarze gospodarczym, społecznym i ekologicznym.

Zaproponowana przez Ignacego Sachsa klasyfikacja kategorii wzrostu i rozwoju społeczno-gospodarczego koresponduje z pojęciem rozwoju potrójnie zrównoważonego, jako głównego kierunku zalecanego obecnie w programach Unii Europejskiej, a także w rzeczonej już ekonomii nowego pragmatyzmu, autorstwa G.W. Kołodki [Kołodko 2014].

Przedstawiona w tabeli 1. klasyfikacja wskazuje na zagrożenie wynikające z fetyszyzowania wzrostu gospodarczego kosztem postępu społecznego i ekologicznego. Prowadzi to do rozmaitych, wyżej przedstawianych, wynaturzeń społeczno-gospodarczych. Szczególnie szkodliwy jest dziki wzrost gospodarczy. 
Tabela 1. Wzrost społeczno-gospodarczy versus rozwój społeczno-gospodarczy

\begin{tabular}{|c|l|c|c|c|}
\hline Lp. & \multicolumn{1}{|c|}{$\begin{array}{c}\text { Kategorie wzrostu } \\
\text { i rozwoju }\end{array}$} & $\begin{array}{c}\text { Sfera } \\
\text { gospodarcza }\end{array}$ & $\begin{array}{c}\text { Sfera } \\
\text { społeczna }\end{array}$ & $\begin{array}{c}\text { Sfera } \\
\text { ekologiczna }\end{array}$ \\
\hline 1. & Dziki wzrost gospodarczy & + & - & - \\
\hline 2. & Wzrost przyjazny społecznie & + & + & - \\
\hline 3. & Wzrost przychylny dla środowiska & + & - & + \\
\hline 4. & $\begin{array}{l}\text { Harmonijny, trwały rozwój } \\
\text { społeczno-gospodarczy }\end{array}$ & + & + & + \\
\hline
\end{tabular}

Źródło: I. Sachs, W poszukiwaniu nowych strategii rozwoju, Gospodarka i Przyszłość, Warszawa 1996, nr 1-4, s. 44

Wiele miejsca tej kwestii poświęca K. Raworth twierdząc, że im bardziej wzrost gospodarczy nie jest zharmonizowany z postępem społecznym i ekologicznym, tym większa dziura w rzeczonym obwarzanku, czy ściślej - amerykańskim paczku, czyli takim, który ma dziurę w środku. Dziura ta zaś jest metaforą destrukcji i zaniedbań społecznych. Natomiast pole samego obwarzanka stanowi metaforę bezpiecznego i sprawiedliwego modelu społecznogospodarczego, eliminującego ubóstwo z jednej strony oraz niszczącą naszą planetę, konsumpcjonistyczną przesadę i nadmiar, z drugiej. Wewnętrzna, dolna krawędź obwarzanka obrazuje cele sprawiedliwości społecznej i dobrobytu, które powinny być rozszerzane, zmniejszając rzeczoną dziurę. Zewnętrzna zaś krawędź wyznacza nieprzekraczalne granice obciążeń naszej planety.

Kate Raworth, używając metafory obwarzanka rekomenduje siedem sposobów ekonomicznego myślenia na miarę XXI wieku. Każdy z nich wychodzi od krytyki siedmiu, zakodowanych w umysłach ludzi, absurdalnie fałszywych obrazów współczesnego świata. Ów fałsz jest destrukcyjny dla społecznego dobrobytu i wymaga eliminacji. Raworth zarysowuje w związku z tym siedem kierunków rozwiązań, zastrzegając zarazem, że jest to zaledwie poczatek nowej koncepcji. Raworth podkreśla zarazem, że w nadchodzacych dekadach zadaniem dla myślicieli ekonomicznych będzie połączenie tych siedmiu nowych sposobów myślenia w praktyce i dodanie wielu kolejnych [Raworth 2021] (tabela 2).

Raworth rekomenduje zatem ukierunkowanie systemu społeczno-gospodarczego i teorii ekonomii na harmonijny rozwój społeczno-gospodarczy - zgodnie z metaforą obwarzanka zamiast ukierunkowania na wzrost PKB. Rekomenduje systemowy holizm i uwzględnianie szerokiej perspektywy zamiast kierowania się uproszczonymi schematami i matematycznymi modelami zgodnie z przyjmowanym w ekonomii neoklasycznej założeniem o ruchu okrężnym dochodu w gospodarce, przypominającym hydrauliczny system przepływu wody w instalacji wodno-kanalizacyjnej. Cechą rekomendowanej przez Raworth „ekonomii obwarzanka” jest ponadto uwzględnianie ludzkiej natury, z jej siłą i słabościami, zamiast przyjmowania nierealistycznego założenia o homo oeconomicus. Zarazem zdaniem Raworth konieczne jest uwzględnianie ewoluowania systemów zamiast nierealistycznego założenia o ich uniwersalizmie i mechanicznej równowadze. Natomiast dla przeciwdziałania nierówno- 
Tabela 2. Od ekonomii i gospodarki XX-wiecznej do XXI-wiecznej

\begin{tabular}{|l|l|l|}
\hline \multicolumn{1}{|c|}{$\begin{array}{c}\text { Siedem sposobów } \\
\text { myślenia }\end{array}$} & $\begin{array}{c}\text { Od ekonomii i gospodarki } \\
\text { XX-wiecznej }\end{array}$ & $\begin{array}{c}\text { Do ekonomii i gospodarki } \\
\text { XXI-wiecznej }\end{array}$ \\
\hline 1. Zmień cel & PKB & ekonomia obwarzanka \\
\hline 2. Dostrzeż pełny obraz & ruch okrężny rynku & gospodarka zintegrowana \\
\hline 3. Pielęgnuj ludzką naturę & $\begin{array}{l}\text { racjonalny człowiek } \\
\text { ekonomiczny }\end{array}$ & $\begin{array}{l}\text { społeczne przystosowanie } \\
\text { ludzi }\end{array}$ \\
\hline 4. Skojarz działanie systemów & mechaniczna równowaga & dynamiczna złożoność \\
\hline 5. Dąż do dystrybucji & wzrost wszystko & redystrybucja z założenia \\
\hline 6. Orientuj się na odnawialność & wzrost wszystko wyczyści & regeneracja z założenia \\
\hline 7. Traktuj wzrost agnostycznie & uzależnienie od wzrostu & obojętność na wzrost \\
\hline
\end{tabular}

Źródło: skrócone opracowanie własne na podstawie [Raworth 2021, s. 32-33]

ściom społecznym konieczna jest redystrybucja dochodów zamiast założenia, że przypływ unosi wszystkie łodzie (teoria skapywania). Dla ochrony naturalnego środowiska niezbędne jest zaś ukierunkowanie systemu społeczno-gospodarczego na odnawialność, regeneracje zasobów zamiast rabunkowej eksploatacji natury. Zasadne tym samym jest agnostyczne podejście do wzrostu gospodarczego, obojętność na wzrost gospodarczy, czyli przejście na model post-PKB-owski (Beyond GDP Economy) jako przeciwwage dla dzikiego wzrostu gospodarczego i niemal narkotycznego wzrostowego uzależnienia.

Już nawet tak ogólna, z konieczności skrótowa prezentacja koncepcji ekonomii obwarzanka wskazuje na obszary zbieżności z koncepcją społecznej gospodarki rynkowej. Przede wszystkim w obydwu tych koncepcjach uwydatniana jest nadrzędność celów społecznych nad czysto gospodarczymi. Społeczna gospodarka rynkowa, podobnie jak „ekonomia obwarzanka", to koncepcje wolnorynkowego ustroju ładu społeczno-gospodarczego, harmonizującego interesy gospodarcze i społeczne, ale też ekologiczne ${ }^{12}$. Podobnie jak w „ekonomii obwarzanka", także w koncepcji SGR wzrost PKB nie jest traktowany jako cel, lecz jako środek do osiagnięcia celu. Bardzo wyraziście eksponował to Ludwig Erhard, według którego: „Nikt nie powinien być tak dogmatyczny, aby jedynie w postępującej ekspansji gospodarczej tzn. w kwestiach materialnych, dostrzegać lekarstwo na wszystko" [Erhard 2012, s. 276]. Rzeczonym celem, zarówno w koncepcji obwarzanka, jak i w koncepcji społecznej gospodarki rynkowej jest dobrobyt społeczny i poprawa jakości życia ludzi.

${ }^{12}$ Co prawda środowisko naturalne i jego ochrona nie stanowiły w czasach Euckena przedmiotu szczególnego zainteresowania nauk ekonomicznych, ale mimo to Eucken prawie proroczo dostrzegał już wówczas problem negatywnych następstw kosztów zewnętrznych (externalities), nieuwzględnianych adekwatnie przez producentów w rachunku kosztów, choć przez nich generowanych. Przytaczał przykłady zniszczonych lasów w Ameryce, czy też fabryk chemicznych, których ścieki zanieczyszczają wody wielu rzek i jezior itp. W takich i innych przypadkach nie wystarcza, zdaniem Euckena, przestrzeganie w polityce gospodarczej ogólnych zasad konkurencyjnego ładu gospodarczego [Eucken 2004]. 
W koncepcji SGR poprzez stosowanie wymienianych już zasad regulujących przebieg procesu gospodarowania, wskazuje się, podobnie jak w koncepcji „ekonomii obwarzanka”, na zasadność redystrybucji dochodów w sytuacji występowania wysoce asymetrycznych, drastycznych nierówności dochodowych, trudnych, bądź niemożliwych społecznie do zaakceptowania. Specjalne zasady regulujące stosowane sa także w sytuacji nieuwzględniania w rachunku ekonomicznym przedsiębiorstw niepożądanych efektów zewnętrznych i występowania anormalnych reakcji po stronie podaży, co - podobnie jak w „ekonomii obwarzanka" - przeczy neoklasycznemu założeniu, że wzrost gospodarczy i wolny rynek samoistnie rozwiązują ten problem [Eucken 2004, s. 291-304].

Mimo podobieństw obydwu koncepcji różnią się one zakresem uwzględnianych procesów społeczno-gospodarczych. Autorka Ekonomii obwarzanka samokrytycznie zastrzega, że wdrożenie i połączenie w praktyce owych siedmiu nowych sposobów myślenia wymaga dodania wielu kolejnych. I w tym sensie koncepcja społecznej gospodarki rynkowej wyróżnia się większą kompleksowością, o czym przesądzają jej zasady konstytuujące. Będące ich przedmiotem zagadnienia sa w „ekonomii obwarzanka” uwzględniane nieco naskórkowo, jedynie pośrednio poprzez analizę rekomendowanych zmian sposobu myślenia o gospodarce i ekonomii, podczas gdy w ordoliberalnej koncepcji SGR zasady konstytuujace traktowane sa jako fundamentalne.

Zarazem jednak obydwie koncepcje, czyli SGR i „ekonomię obwarzanka”, łączy kwestia barier wdrożeniowych. Choć „ekonomia obwarzanka” to koncepcja in statu nascendi, to już na tym etapie jej autorka wskazuje na trudne wyzwania wdrożeniowe. Natomiast koncepcja SGR zderzała się i wciąż się zderza z problemem braku w polityce społecznogospodarczej konsekwencji w realizacji zasad tej koncepcji. Przyczyny słabości polityki społeczno-gospodarczej w egzekwowaniu tych zasad to złożony temat wymagający pogłębionych analiz, ukierunkowanych zwłaszcza na identyfikację presji rozmaitych grup nacisku i grup interesów, co może zmniejszać istotnie determinację wdrażania zmian systemowych, zwiększając ryzyko wadliwości polityki społeczno-gospodarczej, na co zwraca uwagę cytowany już Krugman [2020]. To ryzyko, które może narastać w warunkach nowych wyzwań, jakie wynikają z ogarniającej obecnie świat czwartej rewolucji przemysłowej.

\section{Konkluzja}

Reasumując, można stwierdzić, że w obecnych wysoce turbulentnych, kryzysogennych warunkach fundamentalnym wyzwaniem staje się kształtowanie systemu społecznogospodarczego ładu, ukierunkowanego na eliminację wynaturzeń w tych systemach i przeciwdziałanie zafałszowującym rzeczywistość społeczno-gospodarczą ideom-zombi. Takim wymogom odpowiadaja zasady SGR, jak i ekonomii obwarzanka. Obydwie te koncepcje można wręcz potraktować jak memento dla współczesnego świata. W obydwu tych koncepcjach przestrzega się przed fundamentalizmem rynkowym, błędami pomiaru, przed myleniem środków z celami działalności społeczno-gospodarczej i myleniem wzrostu gospodarczego z harmonijnym rozwojem społeczno-gospodarczym. Wskazuje się przy tym 
na konieczność optymalizacji relacji państwo-rynek. Choć koncepcja społecznej gospodarki rynkowej jest formalnie przejętym przez Unię Europejską modelem ustroju gospodarczego, a w Polsce dodatkowo znajduje umocnienie w art. 20 Konstytucji, to rzeczywistość dalece odbiega od wymogów tej koncepcji. Dlatego też zasadne jest jej synergiczne umacnianie, m.in. poprzez wykorzystywanie innych spójnych z nia, prospołecznych koncepcji, czego przykładem jest koncepcja określana jako „ekonomia obwarzanka”.

\section{Literatura}

Akerlof G.A., Shiller R.J., 2017, Złowić frajera, Ekonomia manipulacji i oszustwa, Polskie Towarzystwo Ekonomiczne, Warszawa.

Arak P., 2021, PANDENOMIA. Czy koronawirus zakończył erę neoliberalizmu? Poltext, Warszawa.

Bałtowski M. (red.), 2016, Ekonomia przyszłości. Wokót nowego pragmatyzmu Grzegorza W. Kołodko, Wydawnictwo Naukowe PWN, Warszawa.

Collier P., 2017, How to save capitalism from itself: Paul Collier on the new pragmatism, https: / / www.the-tls.co.uk/articles/public/ how-to-save-capitalism/ [dostęp: 20.06.2019].

Collier P., 2018, The Future of Capitalism. Facing the New Anxieties, Allen Lane, Penguin Books, London.

Erhard L., 2005, Die Prinzipien der deutschen Wirtschaftspolitik, Orientierungen zur Wirtschafts-und Gesellschaftspolitik, 104.

Erhard L., 2012, Dobrobyt dla wszystkich, Polskie Towarzystwo Ekonomiczne, Warszawa.

Eucken W., 1989, Die Grundlagen der Nationalökonomie, 9. Auflage, Springer Verlag, Berlin-Heidelberg-New York-London-Paris-Tokyo-Hong Kong.

Eucken W., 2004, Grundsätze der Wirtschaftspolitik, 7. Auflage, Mohr Siebeck, Tübingen.

Fiedor B., Gorynia M., Hardt Ł. (red.), 2021, Jednorodność czy pluralizm. Rozważania nad natura nauk ekonomicznych i gospodarki, Polskie Towarzystwo Ekonomiczne, Warszawa.

Fiedor B., Gorynia M., Mączyńska E. (red.), 2020, Nauki ekonomiczne i wyzwania wspótczesności. Fundamentalne problemy w teorii i praktyce, Polskie Towarzystwo Ekonomiczne, Warszawa.

Galbraith J.K., 2011, Ekonomia w perspektywie. Krytyka historyczna, wyd. II, Polskie Towarzystwo Ekonomiczne, Warszawa.

Galloway S., 2017, The Four: The Hidden DNA of Amazon, Apple, Facebook, and Google, Random House Large Print.

Galloway S., 2021, POST CORONA. Biznes w czasach pandemii. Od kryzysu do szans, Mtbiznes.pl. 
IWF-CHEFIN KRISTALINA GEORGIEWA Kanzlerin Merkel und die deutsche Regierung verdienen Respekt, Handelsblatt, 14.05.2020 https:/ / www.handelsblatt.com/politik/international/ iwf-chefin-kristalina-georgiewa-kanzlerin-merkel-und-die-deutsche-regierung-verdienenrespekt/25826576.html, [dostęp: 7.05.2020].

Jakubowicz A., 2021, Marzenia Keynesa a rzeczywistość, Biuletyn PTE, 2, s. 14-17, Warszawa, http:/ / www.pte.pl/pliki /1/68/Biuletyn_2-2021_93.pdf.pdf [dostęp: 30.07.2021].

Keynes J.M., 2020, Ekonomiczne perspektyw dla naszych wnuków, Biuletyn PTE, 4, s. 7-11, http: / / www.pte.pl/pliki/1/68/Biuletyn_21.12.2020.pdf, [dostęp: 7.05.2020].

Kołodko G.W., 2013, Dokąd zmierza świat. Ekonomia polityczna przyszłości, Prószyński i S-ka, Warszawa.

Kołodko G.W., 2014, Nowy pragmatyzm, czyli ekonomia i polityka dla przyszłości, Ekonomista, nr 2. Konstytucja Rzeczypospolitej Polskiej z dnia 2 kwietnia 1997 r. (Dz.U. nr 78, poz. 483).

Krugman P., 2020, Arguing with Zombies. Economics, Politics, and the Fight for a Better Future, WW Norton \& Co, NY.

Kukliński A., 2010, Polonia Quo Vadis? Biuletyn PTE, 6.

Mazzucato M., 2020a, The COVID-19 crisis is a chance to do capitalism differently Government has the upper hand for the first time in a generation. It must seize the moment, The Guardian, 18 Mar.

Mazzucato M., 2020b, Capitalism's Triple Crisis, Mar 30, https://www.project-syndicate. org / commentary / covid19-crises-of-capitalism-new-state-role-by-mariana-mazzucato-202003?barrier=accesspaylog [dostęp: 30.06.2020].

Mączyńska E., 2014, Dylematy pomiaru gospodarki globalnej-produkt krajowy brutto [w:] A. Cieślik, J.J. Michałek (red.), Niedoskonała globalizacja. Czy światowy system gospodarczy wymaga gruntownych reform? Wydział Nauk Ekonomicznych, Uniwersytet Warszawski, Warszawa.

Mączyńska E. (red.), 2019, Ekonomia i polityka. Wokół teorii Grzegorza W. Kołodko, Wydawnictwo Naukowe PWN, Warszawa.

Mączyńska E. 2020a, Społeczna Gospodarka Rynkowa. Archaiczny pleonazm czy remedium? [w:] E. Mączyńska. P. Pysz (red.), Społeczna Gospodarka Rynkowa i integracja europejska w czasach dziejowego przełomu, Polskie Towarzystwo Ekonomiczne, Warszawa.

Mączyńska E., 2020b, Zniewolony konsument na wolnym rynku w gospodarce globalnej. Destrukcyjne następstwa i możliwości przeciwdziałania [w:] E. Rutkowska-Tomaszewska, W. Kwaśnicki (red.), Ekonomia jako dyscyplina naukowa i kierunek kształcenia. Aktualne trendy i pożadane zmiany, Difin, Warszawa.

Mączyńska E., 2021, Zniewolony konsument na wolnym (?) rynku https:/ / www.obserwatorfinansowy.pl / tematyka / makroekonomia/trendy-gospodarcze/ zniewolony-konsument-na-wolnym-rynku/ [dostęp: 7.07.2021]. 
Mączyńska E., Pysz P., 2014, Liberalizm, neoliberalizm i ordoliberalizm, Ekonomista, 2.

Mączyńska E., Pysz P. (red.), 2020a, Społeczna Gospodarka Rynkowa w czasach dziejowego przełomu, Polskie Towarzystwo Ekonomiczne, Warszawa.

Mączyńska E., Pysz P., 2020b, Po co nam w XXI wieku Społeczna Gospodarka Rynkowa? [w:] B. Fiedor, M. Gorynia, E. Mączyńska (red.), Nauki ekonomiczne i wyzwania współczesności. Fundamentalne problemy w teorii i praktyce, Polskie Towarzystwo Ekonomiczne, Warszawa.

Münchrath J., 2021, Paul Krugmans „Der Kampf gegen Zombies“ ist seine eigene Siegeserklärung, Handelsblatt, 3.07., https: / / www.handelsblatt.com/arts_und_style/literatur/buchrezension-paul-krugmans-der-kampf-gegen-zombies-ist-seine-eigene-siegeserklaerung-/27381900. html [dostęp: 20.07.2021].

Mirowski P., Plehwe D., 2009, The Road from Mont Pelerin: The Making of Neoliberalism, Harvard University Press, Cambridge.

Opolski K., Turowski K., 2020, Historia ludzkiej chciwości, Wydawnictwo ARKADY, Warszawa. Piketty T., 2020, Capital and Ideology, Harvard University Press.

Pysz. P., Grabska-Jurczuk A., 2021, Ordoliberalna koncepcja Społecznej Gospodarki Rynkowej w dobie postpandemii [w:] E. Mączyńska, P. Pysz, Społeczna gospodarka rynkowa w dobie pandemii i postpandemii, Polskie Towarzystwo Ekonomiczne, Warszawa.

Ratajczak M., 2014, Ekonomia i edukacja ekonomiczna w dobie finansyzacji gospodarki, Ekonomista, 2.

Raworth K., 2017, Doughnut economics: seven ways to think like a 21st-century economist. Random House, New York.

Raworth K., 2021, Ekonomia obwarzanka. Siedem sposobów myślenia o ekonomii XXI wieku, Wydawnictwo Krytyki Politycznej, Warszawa.

Rodrik D., 2002, After Neoliberalism, What? Project Syndicate, September, http:/ /www.project-syndicate.org/commentary/rodrik7/English [dostęp: 20.07.2021].

Rodrik D., 2019, Rządy ekonomii, Wydawnictwo Naukowe PWN, Warszawa.

Roubini N., Mihm S., 2011, Ekonomia kryzysu, Oficyna Wolters Kluwer business, (tytuł oryg. Crisis Economics: A Crash Course in the Future of Finance, 2010).

Rutkowska-Tomaszewska E., Kwaśnicki W., 2020, Ekonomia jako dyscyplina naukowa i kierunek kształcenia. Aktualne trendy i pożądane zmiany, Difin, Warszawa.

Sachs I., 1996, W poszukiwaniu nowych strategii rozwoju, Gospodarka i Przyszłość, 1-4.

Schwab K., 2018, Czwarta rewolucja przemystowa, Wydawnictwo Studio EMKA, Warszawa.

Skidelsky R.,2011, Democracy or Finance, Project Syndicate, April 18, http:/ / www.skidelskyr. com/site/article/democracy-or-finance/ [dostęp: 20.12.2016]. 
Steinmetz-Jenkins D., 2020, Thomas Piketty: Confronting Our Long History of Massive Inequality, "The Nation", March 26, https: / / www.thenation.com/article/culture/thomas-piketty-interview-inequality-book-covid/ [dostęp: 30.06.2020].

Stiglitz J.E., 2020a, Ein Trauma für dieWeltwirtschaft, Handelsblatt, Mittwoch, 6. 05. I., nr 87.

Stiglitz J.E., 2020b, Ludzie chca zysku, nie wyzysku, Wydawnictwo Naukowe PWN, Warszawa.

Stiglitz J.E., Fitoussi J.P., Durand M., 2019, Poza PKB. Mierzmy to, co ma znaczenie dla rozwoju społeczno-gospodarczego, Polskie Towarzystwo Ekonomiczne, Warszawa.

Stiglitz J.E., Sen A.A., Fitoussi J.-P., 2013, Błąd pomiaru. Dlaczego PKB nie wystarcza, Polskie Towarzystwo Ekonomiczne, Warszawa.

Taleb N.N., 2013, Antykruchość, Kurhaus Publishing, Warszawa.

Taleb N.N., 2014, Czarny Łabędź, Kurhaus Publishing, Warszawa.

Nassim Taleb Says 'White Swan' Coronavirus Pandemic Was Preventable, Bloomberg, March 30th, 2020, https: / / www.bloomberg.com/news / videos/2020-03-30/nassim-taleb-says-whiteswan-coronavirus-pandemic-was-preventable-video [dostęp: 20.05.2020].

Traktat o Unii Europejskiej, Wersja skonsolidowana, 2008, http://eur-lex.europa.eu/ LexUriServ / LexUriServ.do?uri=OJ:C:2008:115:0013:0045:pl:pdf [dostęp: 9.05.2008].

Traktat ustanawiający Konstytucję dla Europy, 2004, (Dz.U. UE C 310, t. 47, 16 grudnia).

Virus lays bare the frailty of the social contract. Radical reforms are required to forge a society that will work for all, 2020, Financial Times, April 3, https: / / www.ft.com/ content/7eff769a-74dd-11ea-95fe-fcd274e920ca [dostęp: 20.05.2020].

Weizsäcker E.U., Wijkman A. i in., 2018, Ejże! Kapitalizm, krótkowzroczność, populacja i zniszczenie planety, Raport Klubu Rzymskiego, IBS, Politechnika Warszawska, Warszawa.

WHO Coronavirus (COVID-19) Dashboard, 2021, https: / covid19.who.int/ [dostęp: 25.07. 2021]. Wilkin J., 2014, Dlaczego ekonomia straciła duszę? Biuletyn PTE, 1.

Wilkinson R., Pickett K., 2011, Duch równości. Tam gdzie panuje równość wszystkim żyje się lepiej, Wydawnictwo „Czarna Owca”, Warszawa. 


\section{Crises as an impulses for changes in socio-economic systems}

\section{ABSTRACT}

The analyses presented in this essay are aimed at identifying potential directions of rationalization of socio-economic systems, designed not only for counteracting crisis destructions, but most of all the current global crisisogenicity. The need to search for rationalising solutions is not only demonstrated by the crisis that is encompassing the world in connection with the COVID-19 pandemic and which exposes the systemic dysfunctions of the global economy. This is also confirmed by the crisis multiplication characteristic of the modern world and already occurring before the pandemic, i.e. the overlapping of various crises, which creates a specific thickening crisis network. This intensifies discussions and questions concerning possible future directions of change in socio-economic systems. These questions are even more important because of the persisting neoliberal so-called zombi-ideas, i.e. ideas which, despite the fact that reality absolutely does not confirm their validity, are artificially and in the interest of narrow social groups kept alive and constitute a barrier to restoring order in the local and global dimension. In this context, this essay analyzes concepts that differ from the neoliberal ones, including the concept of Doughnut economics by British economist Kate Raworth. This economist demonstrates that the more economic growth is not in harmony with social and ecological progress, the larger the hole inside the doughnut is. The centre hole of the model is a metaphor for social destruction and neglect. However, the field of the doughnut itself is a metaphor for a safe and just socio-economic model, eliminating poverty on the one hand and planet-destroying consumerist excess on the other. The inner bottom edge of the doughnut illustrates the goals of social justice and welfare, which should be expanded reducing aforesaid hole. The outer edge determines the impassable limits of the burdens on the natural environment. The relationship between this concept and the ordoliberal model of the social market economy is analyzed. By definition, it is a model of political system focused on socio-economic order, a model with a treaty and constitutional status in the European Union countries. Ordo means order. However, the formal enshrinement of this model does not fully translate into socio-economic reality. Therefore, this model needs to be strengthened and adapted to the requirements of the fourth industrial revolution encompassing the world nowadays. The analyses presented in this essay indicate that this reinforcement could be achieved through combining the intellectual potential of the SOME (social market economy model) model and the Doughnut economic model. Both of these concepts have in common their pro-social orientation, harmonizing economic, social and environmental objectives, balancing the socio-economic system, which prevents the occurrence of asymmetries that are harmful to socio-economic development.

Key words: social market economy, neoliberalism, ordoliberalism, Doughnut economics, COVID-19 pandemic, ordo; JEL classification codes: A14, E02, E65, O43, P20

Elżbieta Mączyńska, prof. dr hab. - profesor nauk ekonomicznych, zwiq̨zana ze Szkołą Główną Handlowq w Warszawie; organizatorka i kierownik prowadzonych w SGH Podyplomowych Studiów Wyceny Nieruchomości. Członkini Rady Naukowej Instytutu Nauk Ekonomicznych PAN, Prezydium Komitetu Prognoz „Polska 2000 Plus”, Komitetu Nauk Ekonomicznych Polskiej Akademii Nauk oraz Narodowej Rady Rozwoju. Prezes Polskiego Towarzystwa Ekonomicznego. Specjalistka z dziedziny ekonomii, w tym analizy ekonomicznej, finansów i wyceny przedsiębiorstw, systemów gospodarczych oraz strategii rozwoju społeczno-gospodarczego. Autorka około 300 publikacji z tego zakresu. Kreatorka modeli predykcji bankructwa. Więcej informacji: http://prezes.pte.pl/ (zk@pte.pl)

Elżbieta Mączyńska, Prof. PhD - professor of economic sciences, affiliated with the Warsaw School of Economics (SGH); organizer and manager of the Postgraduate Real Estate Valuation Studies at SGH. Member of: the Scientific Council of the Institute of Economic Sciences of the Polish Academy of Sciences; the "Poland 2000 Plus" Committee Presidium; the Economic Sciences Committee of the Polish Academy of Sciences and the National Development Council. President of the Polish Economic Society. Specialist in economics, including economic analysis, finance and enterprise valuation, economic systems and strategy of socio-economic development. The author of c.a. 300 publications on these subjects. The creator of bankruptcy prediction models.

More information: http://prezes.pte.pl/(zk@pte.pl) 